\title{
Representations of rural lesbian lives in young adult fiction
}

\author{
Wendy Keys ${ }^{a}$, Elizabeth Marshall ${ }^{b}$ and Barbara Pini ${ }^{c}$ \\ ${ }^{a}$ School of Humanities, Languages and Social Science, Griffith University, Nathan, Australia; ${ }^{b}$ Faculty of \\ Education, Simon Fraser University, Burnaby, Canada; 'School of Humanities, Languages and Social Sciences, \\ Griffith University, Nathan, Australia
}

\begin{abstract}
This paper examines representations of rural lesbian lives in three young adult novels. The novels analysed are Beauty of the broken by Tawni Waters (2014), Julie Anne Peters (2005) Pretend you love me, and Forgive me if you've heard this one before by Karelia StetzWaters (2014). The first of the novels by Waters (2014. Beauty of the broken. New York, NY: Simon Pulse) presents a very negative portrait of rural life for queer youth. Its message is that the only positive queer life is one that is lived in the urban. In contrast, the texts by Peters (2005. Pretend you love me. New York, NY: Little Brown) and Stetz-Waters (2014. Forgive me if you've heard this one before. Portland, OR: Ooligan Press) present rural spaces as potentially both inclusive and exclusive for queer youth. These novels also demonstrate that urban spaces can be equally problematic for queer youth. While we do not discount that Waters (2014. Beauty of the broken. New York, NY: Simon Pulse) description of rural life may be the experience of some queer youth, we argue that the novels by Peters (2005. Pretend you love me. New York, NY: Little Brown) and Stetz-Waters (2014. Forgive me if you've heard this one before. Portland, OR: Ooligan Press) offer a more nuanced and complicated notion of place and its relationship to non-normative sexual subjectivities.
\end{abstract}

\section{KEYWORDS}

Lesbian; youth adult fiction; rural; queer

\section{Introduction}

In a comprehensive review of the geographical literature on rural children and youth, Powell, Taylor, and Smith (2013) make no mention of sexuality. In their list of identified gaps and suggested avenues for future research, the authors argue that there is a crucial need to understand how the lives of rural young people intersect with a range of social locations, and yet queer subjectivities are overlooked. This oversight is surprising and concerning given that geographers know little about the lives of queer youth (Pini, Morris, \& Mayes, 2016; Schroeder, 2015), and, more particularly and pertinently, even less about the lives of rural queer youth (Pini, Keys, \& Marshall, 2017; Rodo-de-Zarate, 2015).

In this paper we contribute to knowledge about rural queer youth through a textual analysis of three young adult novels that feature lesbian protagonists. Such novels can contribute to a 'queer pedagogy' subverting dominant discourses of heterosexuality and educating students, teachers and parents about the lives of youth whose sexual 
subjectivities are outside the norm (Bach, 2016). They can also provide an educative role for queer youth themselves allowing them to see their experiences and concerns reflected back at them (Clark \& Blackburn, 2016). This is not to suggest, however, that the inclusion of queer characters in fiction for youth is always indicative of a radical or progressive pedagogy as such fiction may reproduce rather than challenge hegemonic scripts of sexual subjectivity (Blackburn, Clark, \& Martino, 2016). At the same time this highlights the need for critiquing the growing genre that is queer novels for youth, including the subgenre that is set in a rural location.

The novels analysed are Beauty of the broken by Tawni Waters (2014), Julie Anne Peters (2005) Pretend you love me, and Forgive me if you've heard this one before by Karelia StetzWaters (2014). These texts are part of a substantial growth in queer writing for youth which has occurred in the years since the publication of what is typically named the first gay young adult novel, John Donovon's (1969) I'll get there. it better be worth the trip. This increase in queer Young Adult Fiction has generated a related increased scholarly interest in the subject. There has subsequently been work monitoring the genre's representation in awards for young adult literature (Jimenez, 2015), surveying its treatment in media reviews (Rothbauer \& McKechnie, 2000) and recording its provision in public libraries (Chapman, 2013). Alongside these studies, scholars have detailed and critiqued the representation of sexualities in the genre noting generic themes, tropes, silences and devices (Jones, 2013; Trites, 1998; Wickens, 2011).

What commentators have overlooked in much of this work are the spatial dimensions of power, identities, practices and relations as they pertain to queer adolescent sexualities. An important exception however is Brown's (2006) analysis of Brent Hartinger's (2003) Geography club. Brown (2006) examines the author's use of spatial metaphors in the novel and the ways in which these are given material form. Relatedly, he takes a spatial lens to the literary concepts of metonym and synecdoche and maps the fluidity of the main character's movement across spaces (public/private, in/out) and into moments of placelessness thus extending and complicating our understanding of how queer lives are lived.

In this paper, we take up Brown's (2006) invocation that there is much we can learn about queer youth by reading Young Adult Fiction through a 'decidedly geographic perspective' (p. 334). We focus on each of the three novels separately detailing the micro-politics of belonging, and identify formation for queer rural youth across a range of scales including home, school, church and community. Concomitantly we identify how rural and urban environments are represented in the texts as places of inclusion and/or exclusion for queer youth.

Beauty of the broken by Tawni Waters (2014).

Both the cover and title of Tawni Waters' (2014) Beauty of the broken convey the contradictory themes of despair and hope at the centre of the novel. Waters' cover features two young women in silhouette holding hands against a haunting dark colour palette. Above the women is a series of rippling concentric circles. The grey hues suggest malevolence and maliciousness evoking the bleak themes of the book, yet the clasped hands convey intimacy and attachment. Further, while the background against which they are pictured is cloudy, shadowy and haunting, the girls are photographed in the foreground so that they appear to be walking away from or towards something and doing so in unison. Meanwhile, the title communicates the idea that new, rich possibilities may emerge from destruction and hardship. 
The 'broken' referenced by the title is undoubtedly the central character, Mara. She is 15, lives with her brother lggy, 17, and her parents in the small town of Barnaby in New Mexico. Mara's father is an extraordinarily violent alcoholic who she tells us can 'go from glad to mad in two seconds flat' (Waters, 2014, p. 105). He's a vicious and cruel man who drowns his daughter's kittens and beats lggy so badly and regularly that he suffers from brain damage. Meanwhile his violence towards Mara's mother leads to her hospitalisation with a broken jaw. Even though Mara is not out to her family for the majority of the novel she is well aware of her father's vicious and vehement homophobia which is regularly given voice in the family home. She observes,

I remember Daddy sitting in his easy chair, reading aloud from a magazine about how some gay boy got tied to a fence and shot. 'Good', Daddy snorted. 'It's a damned abomination. If I ever found a faggot in this town, l'd do the same thing'. (p. 33)

Religion dominates in the rural community with the Preacher, Reverend Winchell holding an esteemed place in the town and most residents attending church. The type of religion practised is one of fear and hatred. Hell and damnation greet those who do not follow the promulgated literal version of the bible. Particularly dire consequences face those who are queer according to the preaching of the Reverend. In an early scene in the novel he tells his congregation that the New Orleans hurricane was an act of God against the debauchery and the abomination of the city as manifest in the presence of gays and lesbians. He shouts 'God hates homosexuals' to agreement from fellow worshippers (Waters, 2014, p. 48). This revulsion towards queers, expressed in the name of God, causes angst and confusion for Mara. Her queer longings fill her with self-hatred and trepidation. At the same time she has a view of God as loving and accepting of all people, including her. She comments:

I look back up at Jesus, thinking l'd like to introduce myself to him, explain my side of the story, let him know how nice I am. I can't imagine those gentle eyes looking at me with anything but love, no matter what Reverend Winchell says. (p. 49)

Mara's bewilderment at religion is aggravated by the hypocrisy of the supposedly moral small town community. Her father faces no consequences for his violence. Rather, his cruelty is largely ignored or overlooked by those who purport to be upright Barnaby citizens.

Unsurprisingly Mara tries to imagine a life outside of her town where she might live a queer life happily. It is almost unfathomable to her, however, and for most of the book she remains locked in place. This positioning of the queer young person as imprisoned in and by her rural location is highlighted by the barbed wire fences which surround each farm, and the large mountain ranges which encircle the town itself. Mara reflects:

I wonder about the rest of the world beyond these barbed wire fences, those majestic mountains. I wonder about places where fairies and faggots and deviant dykes live, where the roads are mostly asphalt instead of dirt, and cows are never seen. I'd like to see all that someday. I'd like to cut through the wires, scale the mountains, go somewhere where there are other people like me. (p. 55)

Mara would rather be at her fundamentalist school than at home even though it is a space where she is subject to harassment and bullying from the popular Preacher's son, Elijah Winchell. She is an outsider in this space describing herself as largely 'invisible' (p. 27). It is at school that she can see and talk to two new arrivals who become a significant part 
of her coming out. The first of these is Henry Begay, an American Indian who has moved to Barnaby from a nearby reservation. Henry is immediately cast as an outsider and tormented by Elijah and others who label him 'gay'. This is the most pejorative of descriptors in Barnaby. While Henry is heterosexual he does not counter the taunts of the bullies instead explaining to Mara that, 'In my tribe, gays are honoured' (p. 180). As well as giving Mara a different, and, importantly, positive perspective on her nascent queer identity, Henry plays a role in introducing Mara to a more sympathetic, loving and inclusive conceptualisation of God and religion.

The second new arrival at Mara's school is Xylia who has moved to Barnaby from San Francisco. Xylia is sophisticated in her clothing and accessories, as well as in her world view. Her writer father, who remains living in San Francisco, and her artist mother, have taught her to be wary of traditional religion and the gender norms on which it is premised. Relatedly, she is dismissive of prejudice and insularity, demonstrating an acceptance of queer lives that is non-existent in Mara's small town. When confusion, embarrassment and disgust are expressed at the possibility of a male kissing another male during a game of spin the bottle at a party, Xylia nonchalantly tells her classmates that this is a common and ordinary occurrence in San Francisco.

Through Xylia Mara affirms her lesbian identity. She also experiences a different type of home - one of security, love and acceptance. Xylia's mother, Juliette, who drives a red sports car and wears a kimono around the house, represents urban cosmopolitanism like her daughter. The home she has created for her lesbian daughter is a queer friendly space. Mara describes visiting Xylia's house as stepping into a 'fairyland'. Such a description demonstrates how fantastical a queer friendly world seems to Mara. She states: 'Glass fairies and butterflies and birds hang everywhere, dangling from doorways and windows and lampshades. The whole place smells like cinnamon. Outside, a million wind chimes jangle, making the most beautiful music I've ever heard' (p. 118). Through her relationship with Xylia, Mara has the opportunity to imagine a future home that departs from the home she has known growing up. She provides a whimsical description of a home marked by ease, freedom and autonomy:

We talk about running away some more and decide that we should have purple carpet, and one of those big couches with only one arm, so we can lie down on it and eat grapes. We also decide to have a pool inside, so we can swim even when it's raining and not worry about being hit by light night. (p. 218)

Soon after this reflection Mara's life takes a dramatically tragic turn. She is raped and outed by Elijah Winchell. Notably, this occurs near the river, a place that Mara had scoped out to feel safe and free from her father's violence. It is here that Mara and Xylia spend time together as a couple and where Henry meets them to enjoy their friendship. When Mara's father discovers she is a lesbian he tries to attack her, but is stopped by lggy. As a result of this intervention lggy is banished from the family home by her father and dies homeless; he is shot while living under a bridge in Albuquerque. Xylia's mother, concerned for her daughter's safety in a town 'stuck in the Stone Age' (p. 276), sends her back to live with her father in San Francisco. Mara is bereft.

Against this unfathomable sorrow Mara decides to leave for San Francisco. The book ends with her committing to do anything she has to do in order to get to the city. She imagines the welcome she will receive from Xylia stating, 'I can almost see her now, 
smiling that light-up-the-night smile. "Mara!" she'll say as she opens the door and throws her arms around my neck' (p. 359). In reaching such a conclusion the book suggests a welcoming and affirming home awaits Mara in the city.

Pretend you love me by Julie Anne Peters (2005).

It is not violence but depression, agoraphobia and an eating disorder which render home a problematic space for Mike in Pretend you love me (Peters, 2005). Mike, whose real name is Mary Elizabeth, lives in the small Kansas town of Coalton with her mother and 24-year-old brother Darryl. Mike's mother has become obese following the suicide of her father a year beforehand, and the earlier death of her baby sister. Although her mother needs surgery desperately, there is no hospital nearby and the family who, according to Mike, live at 'the lower end of the social scale in Coalton', cannot afford it (Peters, 2005, p. 143). Like her father before he died, Mike's mother is also clearly in need of professional help to address her mental health problems. However, as Mike observes wryly, 'the closest thing we have to a shrink' in Coalton is 'Renata, who reads people's horoscopes for ten bucks a pop' (p. 175). The novel thus brings to the fore social issues confronting those who live outside the urban sphere, and the material inequalities of rural living.

Mike's mother never leaves the home nor does she talk to her daughter. Mike spends little time at home - a place where she feels trapped and suffocated. Instead of home as a refuge, Mike explains 'Coalton High was my refuge' (p. 4). Here Mike is taught by the warm, generous and wise Ms S, and the new Principal and replacement softball coach, Mrs Kinneson. The latter takes a special interest in Mike inviting a recruiter from Kansas State University to come and watch her play, and encouraging her to dream of a life outside the confines of the town.

This is not to suggest that Mike is discriminated against in Coalton because of her sexuality. Unlike the other novels, Mike's queer identity is not an issue in the rural community. Nor indeed is the queer identity of Jamie, Mike's best friend, problematic for Coalton residents. As well as lavishing love on to Jamie, his parents also provide support and care for Mike. His mother, in particular, acts as a maternal figure in Mike's life baking her cakes and giving her hugs.

If we had discrimination, I wasn't aware of it. Jamie and I had grown up here. People knew us; they were used to us. I'm sure they gossiped, but it ever got back to me. I never, for one day, felt judged or excluded or persecuted in Coalton. (pp. 153-154)

As is evident from her nick-name, Mike's character is imbued with masculinity. Her gender is a source of curiosity and ambiguity so that characters who meet her for the first time question whether she is male or female. She wears muscle t-shirts and boxer shorts, enjoys lifting weights and softball, and works part-time delivering heavy bags of fertiliser to farms in the district. She explains that she had envisaged taking over her father's plumbing business prior to his death. She is skilled in the trade from working alongside her father and uses these skills throughout the novel.

It is Mike's gendered identity which leads people to assume she is gay, as is illustrated in one of her early encounters with new girl Xanadu. Xanadu comes to live with her aunt and uncle while on probation. We are told that one of Xanadu's friends died from an ecstasy tablet she had given her. As Mike is unloading feed from her truck Xanadu asks: 'I'm stating the obvious here, but you're gay, right? Is this like your total butch look?' (p. 27). While the 
identity of butch lesbian is, of course, legitimate, it is also a potentially problematic to characterise Mike through conflated discourses of hegemonic masculinity and lesbianism. This is particularly the case given the representation of Jamie as both gay and hyper feminine. Jamie spends his time tanning at the local solarium and obsessing about his looks, participating as a member of the school cheer leading squad, (for which he wears short skin-tight shorts), and working at the local Dairy Delite, where he enjoys wearing his candy stripe uniform. If the definition of being gay is feminine, Jamie's hyper femininity marks him as 'the world's queerest queer' (p. 45). Such a description, like those which link Mike's masculinity and sexuality problematically reproduce tired and constraining normative ideologies of gender and sexuality. In this respect the queer characters created by Peters are disappointingly reductive.

Despite the presence of Jamie and acceptance in the rural community Mike, like other rural lesbian protagonists, feels the isolation of not being part of a larger lesbian community. This becomes magnified as she falls in love with Xanadu who, in turn, is romantically interested in one of the farming boys. Jamie is active in online queer communities. It is online that he meets his boyfriend James thus showing that new technologies can mitigate against geographical isolation and facilitate the queer connections across space. In contrast, Mike has not used the Internet for forging lesbian alliances. Further her rural and classed position means that she has lacked the mobility taken for granted by many other contemporary youth. She recounts ruefully that the 'farthest I'd ever been from Coalton was Hutchinson, Kansas, on a field trip in fourth grade to the salt deposits' (p. 187). Her lack of access to more cosmopolitan spaces is highlighted when she goes to Denver with Jamie so he can meet up with his boyfriend, James. While the boys picnic together, Mike plays softball in Cheesman Park with a group of lesbian women. Looking around in the park in central Denver she observes, 'There were more gay women here than I knew existed in the world' (p. 193).

Xanadu is dismissive and disparaging about Coalton describing it derisively as 'Totoland' and 'Siberia' (pp. 18, 116). She dislikes its slow pace and limited leisure options. She dismisses community events and activities as well as some community members as backward, insular, and lacking. Like Xanadu, Mike feels her home town to be restrictive and constraining in some respects. In fact, the opening sentences reference the high level of surveillance that is an everyday part of small town living. Here Mike reflects that it was impossible to keep the ladder she and her brother had moved to the town's water tower, to replace the one the council removed following her father's suicide, a secret. She states, 'This was Coalton. Everyone knew everything' (p. 1).

What emerges in the novel, however, is that the proximity that defines rural community life which gives rise to surveillance can also facilitate a culture of care and support. We see glimpses of this as different residents reach out to Mike concerned about her welfare and her mother's well-being. It is conveyed most prominently when a campaign is initiated to fund Mike's attendance at a state softball championship. She is reluctant to accept the money, not wanting to be positioned as needy or a victim. She is aware of the sympathy people have for her as a result of her father's death and her mother's illness. This leaves her feeling vulnerable. On discovering the fundraising on her behalf she states, 'I suddenly felt exposed, bred, every eye in the Merc stripping me naked. Every eye in town would be on me' (p. 165). It is Mike's fear of neediness which is a challenge for her in her rural community rather than her queer identity. In learning to accept being helped and cared for and 
about Mike comes to appreciate her home. While a relationship with Xanadu does not eventuate, Mike can imagine a future happy queer relationship. Her home town would play a key role in this partnership she explains:

And when I found her, I'd bring her to Coalton. I'd show her this town, these people, we'd build a life here. Because Coalton was a good place to make a life, raise a family. This town was a family. It raised me. (pp. 281-282)

Mike's ruminations provide a very different perspective on the rural community as a place of despair, discrimination and exclusion for queer residents. For her rural space is one associated with care and compassion. Mike's observations also challenge the normative queer coming out narrative as requiring a movement from the rural to the urban. Mike is already out in Coalton. She does not have to leave to claim her queer identity. Moreover, while she wants to follow her dreams of education, she plans to return to her hometown one day with a partner. She thus imagines the rural as a positive place for a future queer adult life.

Forgive me if you've heard this one before by Stetz-Waters (2014).

Another complex depiction of rural space for the lesbian teen is conveyed by StetzWaters (2014) in Forgive me if you've heard this one before. The novel tells the story of Triinu Hoffman over four years from the beginning of junior high to the end of senior high. The setting of small town Oregon is crucial as the context for Triinu's story is Oregon's Ballot Measure 9, which, in 1992, sought to prohibit government, including the public education system, from using money or properties to 'promote, encourage or facilitate homosexuality, paedophilia, sadism or masochism' on the basis that 'these behaviors are abnormal, wrong and unnatural and perverse' (State of Oregon, 1992). The measure, which was eventually defeated in November 1992, was primarily supported by the Christian political group, the Oregon Citizens Alliance (OCA). The OCA, along with the violence and divisiveness that marked this period of Oregon's history, necessarily shape the coming out narrative of the novel's central character, Triinu Hoffman. Home is a key dimension in this respect as the author references examples of discrimination and violence directed at queers at home during the campaign. One incident she reads from the newspaper occurs on 6 September 1992 when an unknown party fired on the home of James Grabble and Vince Propo. Both men were killed and Propo's sister, who was visiting the couple, injured. Triinu learns of the men's political activity and the dismissive response of police that 'they could not place a guard outside the house of every homosexual' (p. 222). Another incident concerns a young gay boy in eastern Oregon who, after coming out to his family, had been dragged to the edge of his family property by his cousins and locked in a shed which was then set alight. His mother had called the police, but only after the fire had taken hold.

The violence that Triinu witnesses occurring in queer homes around Ballot Measure 9 is outside her small rural town, so not conflated with rurality. This sends her a powerful message about the ubiquity of queer hatred and the fact that it is not only contained in the rural. Indeed, her own home space is a refuge from hostility and prejudice. She is an only child to Estonian refugees, academics with a fondness for literature whose love for each other and their daughter fills the home. The book's title references the anecdotes Triinu's father enjoys telling her about his growing up always with the caveat of 'Forgive 
Me If I've Told You this Before'. Meanwhile, the biography of Triinu's Estonian grandmother, who comes to live with the family, provides a parallel with 1992 Oregon. We understand that oppression and discrimination, as well as resistance and struggle, occur across temporal and spatial locations.

Religion plays a key role in the novel as is established in the opening chapter. Triinu and her then best friend Isabel are at a summer camp for Lutherans. The youth leader, Jared, who is preaching to the assembled teens reads to them from Leviticus 20;13, which states that a queer life is abhorrent. Of this biblical reference Triinu observes, 'Emmanuel I Lutherans did not talk about damnation; they talked about salmon bakes ... mother-daughter fashion show - hell but no-one in it' (p. 11). In these reflections the author introduces an important theme in the novel, that is, religion can be about intolerance, hatred and exclusion, or may alternatively be about acceptance, love and inclusion. The type of religion espoused by Jared, and by the many proponents of Ballot Measure 9, resemble the former. As Triinu reports later in the novel, in a large field someone had planted a sign reading, 'Three Gay Rights: Hell-Romans 1;27, AIDS-Jude 1;7, Salvation - I Corinthians 6:11' (p.181). Triinu understandably experiences this mode of religion as extremely alienating. This is difficult for her as religion had previously been important in her life. However, by the novel's end Triinu has adopted her own pantheistic understanding of God and religion far removed from fundamentalist hatred. This gives her comfort and inspiration.

At school Triinu is physically and verbally abused on a regular basis by football team star, and principal favourite, Pip Weston. When 'Die You Mother Fucking Dyke Bitch' is scrawled on her locker, it is, like other assaults, minimised and dismissed by the school administration. From the prom to sport to lab class, school in the text is a site for the production and reproduction of heterosexuality and homophobia. It is also a place where conservative gender ideologies are reinforced and any departures from them sanctioned by staff and students. Ultimately, however, Triinu queers the school space attending the prom where she dances with a female student, uses her skills as a photographer, confronts Principal Pim about his treatment of her, and tells him she is indeed queer.

Triinu's forthrightness with her school principal at the novel's end differs from her much more circumspect journey coming out across her high school years. In this respect her story demonstrates that coming out is not necessarily a singular event, but something that is potentially negotiated with each encounter. As a rural lesbian, and one growing up in a pre-Internet era, Triinu's coming out is hampered by a lack of community, knowledge and experience. When first contemplating telling her father she ponders her sense of aloneness and isolation:

For a breathless moment, I thought I might tell him the truth, but I did not know one other gay person in the whole world, let alone someone who had looked their father in the eye and spoke the words, I'm gay. I'm in love'. As far as I had proof, it had never been done. (p. 120)

Triinu lives in world imbued with heterosexuality. Stetz-Waters (2014) demonstrates that her protagonist's longings and desires are pathologised rather than validated, not only by Ballot 9, but by everyday popular culture such as teen magazines and romance novels.

Despite the hostility of the outside world, Triinu's home is a place of respite and rejuvenation. It is a place to cocoon and rejuvenate against the challenges of life. Triinu thinks about this as she contemplates her broken heart when her crush Ursula begins dating a male. 
My parents would be sitting down to a bottle of wine, or eating crackers in the kitchen, or taking bowls of ice cream into the living room, where the last embers of a fire were glowing in the fireplace. The dog drooling at their feet. The cat dozing on the sofa ... it occurred to me that by the following October I would have only a dorm room to return to in the evening when I needed to bind up my heart. (p. 212)

While Triinu's immediate home space is one of love - pre and post coming out - StetzWaters (2014) highlights the broader meanings of home for queer youth in terms of belonging and acceptance within a queer community. In her home town, Triinu laments that she is 'the last dyke in the grass Seed Capital of the World' and longs for being part of something larger (p. 233). She gains an inkling of a home for her lesbian self when she reads a newspaper article talking about queer movement in light of Ballot Measure 9. It explains:

While many lesbians are determined to stay in Oregon to fight the Oregon Citizens Alliance,
others seek more hospitable communities elsewhere. There is a place where lesbian mothers
run the PTA, lesbian doctors staff the local clinic, and lesbian teens have their own prom. Les-
bians have a promised land: it's Northampton, Massachusetts ... I stared at the page. The
photograph showed a street with little cafes, a bookstore, and a row of trees, leafy and
sunlit. There was a place where lesbians went, and it looked a lot like home. (p. 264)

The above quotation highlights that queer antagonisms were not confined to rural Oregan, but also emanated from and seeped into urban spheres to the extent that, in the 1990s, gay and lesbian people, sought refuge out of the state. Further, the refuge sought by the lesbians described above was in the rural space of Northampton, Massachusetts. Queer friendly is thus not necessarily urban.

At the same time as Stetz-Waters (2014) reveals cities to be potentially challenges spaces for queers she also configures urban space as important to affirming Triinu's emergent queer identity. Triinu befriends two other youth at a leadership camp and they sneak out to the tellingly named 'City Nightclub'. Protestors associated with Ballot 9 are outside the club again revealing that urban environments are not necessarily a panacea for queers. However once Triinu and her friends get past them the nightclub is a revelation to her as it is here that she witnesses gays and lesbians in intimate embraces. This is her first experience of a larger queer community, and moreover, a youthful, joyful, fun filled queer community. She thus describes the venture as 'glorious' (p. 168) in what it revealed to her about the life she could lead.

\section{Conclusion}

The three novels analysed in this paper incorporate many of the broad concerns addressed in non-queer Young Adult Fiction such as issues of belonging and acceptance, empathy, leaving home, escape, independence, safety, friendship, education, career, comfort, love and sex. Arguably, however, these issues become more acute, and take different forms when your sexual subjectivity is outside the norm, and when you reside in the rural.

Of the three novels Beauty of the broken (Waters, 2014) is the most negative about the experience of being a rural lesbian youth. The image of rurality it conveys is one of extraordinary violence, narrow mindedness and religious hatred. The natural environment is afforded some prominence as a potential place of safety and attraction for queer youth, 
but these possibilities are sullied by the vicious rape of the central protagonist in the outdoors. The city, as represented by San Francisco, offers the only potential for a fulfilled queer life.

We do not discount the veracity of this experience of life for queer rural youth. Indeed, in an afterward to her book Waters (2014) writes that during book tours across the country she has met 'many who have stories like Mara's' (p. 360). This is a sobering observation. At the same time the novel replicates what Halberstam (2005) has labelled the 'metro-centric' discourse underpinning imaginings of how queer lives are lived. That is, queer identities can only be asserted and sustained through migration to the urban. Notably, at the conclusion of the two other titles examined, Pretend you love me (Peters, 2005) and Forgive me if I've told you this one before (Stetz-Waters, 2014), the central characters of each also plan to move to the city. However, they will do so with some positive memories of belonging in their rural home towns. Moreover, Mike explicitly talks of returning to her small rural community with her future partner. These texts highlight that rural communities can be simultaneously oppressive and empowering environments for queer youth, and that experiences of inclusion/exclusion can shift for them as they move across spaces such as the home, church, school and community. The rural is therefore best described as 'paradoxical spaces' for lesbian youth (Valentine \& Skelton, 2003, p. 849) offering attachment, connection and community while also being a source of alienation, marginalisation and oppression.

\section{Disclosure statement}

No potential conflict of interest was reported by the authors.

\section{References}

Bach, J. (2016). Exploring queer pedagogies in the college-level YA literature course. Discourse: Studies in the Cultural Politics of Education, 37(6), 917-932. doi:10.1080/01596306.2015.1071758

Blackburn, M., Clark, C., \& Martino, W. (2016). Investigating LGBT-themed literature and trans informed pedagogies in classrooms. Discourse: Studies in the Cultural Politics of Education, 37(6), 801-806. doi:10.1080/01596306.2016.1200251

Brown, M. (2006). A geographer reads geography club: Spatial metaphor and metonym in textual/ sexual space. Cultural Geographies, 13(30), 313-339. doi:10.1191/1474474006eu362oa

Chapman, E. L. (2013). No more controversial than a gardening display? Provision of LGBT-related fiction to children and young people in UK public libraries. Library Trends, 61(3), 542-568. doi:10.1353/lib.2013.0010

Clark, C. T., \& Blackburn, M. V. (2016). Scenes of violence and sex in recent award-winning LGBTthemed young adult novels and the ideologies they offer their readers. Discourse: Studies in the Cultural Politics of Education, 37(6), 867-886. doi:10.1080/01596306.2014.936713

Donovon, J. (1969). I'll get there, it better be worth the trip. New York, NY: Harper \& Row.

Halberstam, J. (2005). In a queer time and place: Transgender bodies, subcultural lives. New York: New York University Press.

Hartinger, B. (2003). Geography club. New York, NY: HarperCollins.

Jimenez, L. M. (2015). Representations in award-winning LGBTQ young adult literature from 20002013. Journal of Lesbian Studies, 19(4), 406-422. doi:10.1080/10894160.2015.1057795

Jones, C. E. (2013). From homoplot to progressive novel: Lesbian experience and identity in contemporary young adult novels. The Lion and the Unicorn, 37(1), 74-93. doi:10.1353/uni.2013.0003

Peters, J. A. (2005). Pretend you love me. New York, NY: Little Brown. 
Pini, B., Keys, W., \& Marshall, E. (2017). Queering rurality: Reading the miseducation of Cameron post geographically. Children's Geographies. doi:10.1080/14733285.2016.1252830

Pini, B., Morris, D., \& Mayes, R. (2016). Rural youth: Mobilities, marginalities, and negotiations. In K. Nairn \& P. Kraftl (Eds.), Space, place and environment (pp. 463-480). Springer Singapore.

Powell, M., Taylor, N., \& Smith, A. B. (2013). Constructions of rural childhood: Challenging dominant perspectives.Children's Geographies, 11(1), 117-131. doi:10.1080/14733285.2013.743285

Rodo-de-Zarate, M. (2015). Young lesbians, negotiating public space: An intersectional approach through places. Children's Geographies, 13(4), 413-434. doi:10.1080/14733285.2013.848741

Rothbauer, P. M., \& McKechnie, L. E. (2000). The treatment of gay and lesbian fiction for young adults in selected prominent reviewing media. Collection Building, 19(1), 5-16. doi:10.1108/ 01604950010310848

Schroeder, C. G. (2015). Sanctuary or prison: Queer youth and the family, household and home. Social and Cultural Geography, 16 (7), 783-797. doi:10.1080/14649365.2015.1023824

State of Oregon. (1992). Oregon ballot measure 9. Salem: Oregon.

Stetz-Waters, K. (2014). Forgive me if you've heard this one before. Portland, OR: Ooligan Press.

Trites, R. S. (1998). Queer discourse and the young adult novel: Repression and power in gay male adolescent literature. Children's Literature Association Quarterly, 23(3), 143-151. doi:10.1353/chq. 0.1203

Valentine, G., \& Skelton, T. (2003). Finding oneself, losing oneself: The lesbian and gay 'scene' as a paradoxical space. International Journal of Urban and Regional Research, 27(4), 849-866. doi:10. $1111 / \mathrm{j} .0309-1317.2003 .00487$

Waters, T. (2014). Beauty of the broken. New York, NY: Simon Pulse.

Wickens, C. M. (2011). Codes, silences and homophobia: Challenging normative assumptions about gender and sexuality in contemporary LGBTQ young adult literature. Children's Literature in Education, 42(2), 148-164. doi:10.1007/s10583-011-9129-0

\author{
For final publication please ref to: \\ DISCOURSE: STUDIES IN THE CULTURAL POLITICS OF \\ EDUCATION, 2017 \\ http://dx.doi.org/10.1080/01596306.2017.1306981
}

